\title{
Investment Strategy in Sharia Mutual Funds: Case Study on the Indonesian Capital Market
}

\author{
Zaenal Arifin*, Sri Mulyati \\ Department of Management, Universitas Islam Indonesia, Yogyakarta Indonesia \\ *Corresponding author. Email: zaenalarifin.fe@uii.ac.id
}

\begin{abstract}
Sharia (Islamic) mutual funds, which are one of the securities that are categorized as socially responsible investment funds, are experiencing rapid growth in Indonesia. For this reason, it is necessary to study the strategies to invest in sharia mutual funds in Indonesia. This study uses three aspects to guide investment strategies in sharia mutual funds: previous year's performance of sharia mutual funds, capital market performance, and the characteristics of mutual fund companies. By using data of Islamic mutual fund in Indonesia from 2010 to 2018, this study offers the following strategies. To invest in fixed income mutual funds, select fixed income mutual funds which in the previous period were in the Top 5 returns. To invest in mixed mutual funds, choose newly issued mixed mutual funds, especially when that year there were several new mixed mutual funds offered. For stock mutual funds, choose mutual funds with the cheapest transaction costs and when the stock market is estimated to have good prospects.
\end{abstract}

\section{Keywords: Sharia Mutual Fund, Performance, Performance Persistence, Sharia Mutual Fund Characteristics}

\section{INTRODUCTION}

The growth of sharia mutual funds in Indonesia is quite high. In 2010, there were only 48 Islamic mutual funds in Indonesia, with the net asset value of around Rp 5 trillion. At present, in 2019, the number of mutual funds has increased to 243 with a net asset value of more than Rp 35 trillion (Sharia Mutual Fund Statistics April 2019, Financial Services Authority, OJK, Indonesia). This development shows great interest from investors in Indonesia to invest in sharia mutual fund products. Increasing investor interest in Islamic mutual funds is consistent with the interest of global investors to prefer financial products that are in accordance with ethics. Jones et. al. (2008) even found that investors are willing to get lower returns when choosing financial products that are categorized as socially responsible investment (SRI) funds.

The increasing number of Islamic mutual funds should be balanced with the increasing ability of investors to choose the best Islamic mutual fund products. Indeed, one of the reasons investors choose mutual funds is because they do not need to have the ability to choose securities as the task has been handed over to investment managers who manage mutual funds (see Bodie, Kane, and Marcus, 2014). However, investors still have to decide in which mutual fund to invest.

The basic strategy of choosing mutual funds is to choose the best performing mutual fund in the previous period. This strategy is based on a number of research findings that show the persistence of mutual fund performance (see Grinblatt and Titman, 1992 and Gruber 1996). Persistent performance means that, if a mutual fund has good performance in a period, the mutual fund will have good performance in the next period. However, the results of the study also found that performance persistence was of limited duration. Zeng (1999), for example, found that persistence would only last less than 30 months. Dwianggoro et al. (2012), using mutual fund data from Indonesia, found that there was a persistence of mutual fund performance in the short term, but in the long term (five years) there was no longer any performance persistence.

In addition to the limited duration of performance persistence, persistence is also influenced by years of observation. Arifin and Mulyati (2017) and Arifin (2018), using data from Islamic mutual funds in Indonesia, found the persistence of mutual fund performance during 2010-2011, but not during 20122016. Arifin (2018) also found that performance 
persistence was influenced by the types of sharia mutual funds. The sharia mixed mutual funds have the highest persistence in performance, followed by sharia fixed income mutual funds, and the least persistent are sharia stock mutual funds.

Looking at the results of the research above, it seems that, in investing in mutual funds, including Islamic mutual funds, investors cannot rely entirely on performance persistence. Because the persistence of performance is uncertain, investors need to identify factors that influence performance persistence. In addition, investors also need to identify factors that influence the roots of performance persistence, namely the performance themselves. The investment strategy in Islamic mutual funds must involve identifying factors that affect the performance of mutual funds as well as the persistence of the performance of the mutual fund. This study examines investment strategies in Islamic mutual funds by considering the performance in the previous period, capital market conditions, and the characteristics of mutual fund companies.

\section{LITERATURE REVIEW}

The persistence of mutual fund performance is an indication of the ability of investment managers to choose securities. A mutual fund whose investment manager is able to choose securities will make his mutual fund perform better than other mutual funds. If the investment manager can maintain his ability to choose securities, then the performance becomes persistent.

Carhart (1997) found the persistence of mutual fund performance, as measured by a four-factor-model that he developed himself. The model is the development of the three-factor-model of Fama and French (1993) with one factor added, namely momentum anomaly, as initiated by Jegadeesh and Titman (1993). Although finding persistence, Carhart (1997) also found that the persistence occurred not because of the ability of investment managers to choose securities but because there are common factors in stock returns and there are differences in mutual fund expenses and transaction costs.

Carhart's (1997) finding that performance persistence is not because of the ability of investment managers is rather surprising. Investors who buy mutual funds hope that the funds they invest will get optimal results because they are managed by investment experts. Because investors feel they are not able to carry out careful analysis and assume that investment managers can, investors decide to invest their funds in mutual funds. However, Carhart's (1997) findings are supported by a number of findings in various countries. Cuthbertson and Nitzsche (2013) conducted research on the ability of investment managers in stock selection and market timing in mutual funds in Germany. They did find investment managers' ability in market timing, but if they used "total" capabilities, which included market timing and stock selection, the conclusion was that investment managers were not able to perform significantly better. The results of research by Chen, Chuang, Lin, and Lan (2013) in the Taiwan capital market also concludes that investment managers in mutual funds as a whole are not able to perform better. However, in Taiwan, unlike the findings in Germany, investment managers are actually able to do stock selection but are unable to do market timing.

In the case of Islamic mutual funds, the persistence study of the performance of Islamic mutual funds is still limited. Khamlichi et al. (2014), using data from the Dow Jones Islamic Index, found that there was no persistence in the performance. Arifin (2018), using data from Islamic mutual funds in Indonesia during 2010 2016, found that there was persistence in the performance during 2010-2011 but not during 20122016. When the performance is not persistent, the investment manager can also be considered not able to perform better consistently. However, the research of Mansor and Bhatti (2011) found the ability of stock selection and market timing for cases of Islamic mutual funds in Malaysia during 1990-2009. This provides an opportunity to examine the same in Indonesia.

When the performance of Islamic mutual funds in Indonesia is often not persistent, the investment strategy in Islamic mutual funds cannot rely on the performance of mutual funds in the past years. The question is: If it does not refer to the performance of previous years, what information can be used as a guide to investing in Islamic mutual funds? Perhaps the performance of the previous period can still be one of the factors considered in choosing Islamic mutual funds. However, we need to add a number of other factors that must be considered. These factors can be grouped into: mutual fund performance factors, capital market performance factors, and mutual fund characteristic factors. These three factors are examined in this study to serve as the basis for investment strategies in Islamic mutual funds.

\section{RESEARCH METHOD}

\subsection{Sample}

The sample of this research are Islamic mutual funds in Indonesia which were traded from 2010 to 2018. This study only analyzes stock, fixed income, and mixed sharia mutual funds. Money market funds are not analyzed because of the limited number of products offered. 


\subsection{Research Model}

The research model is as follows:

$$
\begin{array}{ll}
\text { RETi,t }= & \beta 0+\beta 1 \text { RTM1i,t }+\beta 2 \text { TOP5i, } t+\beta 3 \\
\text { HOTi,t }+ & \beta 4 \text { FUNDi,t }+\beta 5 \text { LAUNCHi, }+\beta 6 \\
\text { MGRi,t } &
\end{array}
$$

where:

RET: Sharia Mutual Fund Performance;

RTM1: the performance of mutual funds in the previous period;

TOP5: the relative performance of mutual funds;

HOT: capital market condition;

FUND: funds under management;

LAUNCH: the length of mutual funds issued; and

MGR: mutual fund managers.

\subsection{Operationalization of Variabels}

\subsubsection{Sharia Mutual Fund Performance}

Sharia Mutual Fund Performance is the monthly accumulated return in one year based on monthly return data issued by PT. Bareksa Investment Portal https://www.bareksa.com.

\subsubsection{Performance Of Mutual Funds In The Previous Period}

The performance in the previous period is the sharia mutual fund performance in the previous year.

\subsubsection{The Relative Performance Of Mutual} Funds

The relative performance of mutual funds in the previous year is measured by whether the mutual funds are in the Top 5 or not the last year.

\subsubsection{Capital Market Condition}

Capital market condition is measured by the number of new mutual fund products in the year of observation, which reflects whether that year was a "hot" or "cold" issue.

\subsubsection{Funds Under Management}

Funds under management is measured by the amount of funds under management in millions of rupiah.

\subsubsection{The Length Of Mutual Funds Issued}

The length of mutual funds issued is measured by the length of time from when the mutual fund was issued until the year of observation.

\subsubsection{Mutual Fund Manager}

Mutual fund manager is measured by whether the owners of the mutual fund are domestic or foreign.

\section{RESULT AND DISCUSSION}

\subsection{Research Findings}

In this study, we tested the model for predicting mutual fund returns (RET) based on three groups of factors: the performance of the previous period mutual funds, capital market performance, and mutual fund characteristics. The previous period's mutual fund performance is proxied by the previous period return (RTM1) and whether the mutual fund performance is in the Top 5 in the previous period (TOP5).

The capital market performance was proxied by how many newcomer mutual fund products in that period (HOT). The more new mutual fund products there are, the better the capital market performance is. This idea is analogous to the "hot and cold" condition in the case of an initial public offering (IPO) as stated, by, e.g., Agathee, Brooks, and Sannassee (2012). The characteristics of mutual funds are proxied by the amount of funds under management (FUND), the length the mutual fund has been issued (LAUNCH), and the management of mutual funds, whether domestic or foreign (MGR). The test results of independent factors on mutual fund returns are shown in Table I. 
Table 1. The results of independent variables' influence testson mutual fund performance.

\begin{tabular}{|c|c|c|c|c|c|c|c|c|}
\hline \multirow{3}{*}{$\begin{array}{l}\text { Ind. } \\
\text { Variables }\end{array}$} & \multicolumn{8}{|c|}{ Types of Mutual Funds } \\
\hline & \multicolumn{2}{|c|}{$\begin{array}{l}\text { All Types of } \\
\text { Mutual Funds }\end{array}$} & \multicolumn{2}{|c|}{$\begin{array}{l}\text { Stock } \\
\text { Mutual Funds }\end{array}$} & \multicolumn{2}{|c|}{$\begin{array}{l}\text { Fixed Income } \\
\text { Mutual Funds }\end{array}$} & \multicolumn{2}{|c|}{$\begin{array}{l}\text { Mixed } \\
\text { Mutual Funds }\end{array}$} \\
\hline & Coeff. & $\begin{array}{l}\text { P- } \\
\text { value }\end{array}$ & Coeff. & $\begin{array}{l}\text { P- } \\
\text { value }\end{array}$ & Coeff. & $\begin{array}{l}\text { P- } \\
\text { value }\end{array}$ & Coeff. & $\begin{array}{l}\mathrm{P}- \\
\text { value }\end{array}$ \\
\hline RTM1 & -1.03 & 0.5 & -6.64 & 0.215 & 0.075 & 0.92 & -0.079 & 0.593 \\
\hline TOP5 & -89.29 & 0.363 & -110 & 0.662 & 14.94 & $.046 *$ & -5.8 & 0.647 \\
\hline HOT & -6.39 & 0.697 & -32.8 & 0.411 & -0.661 & 0.661 & 5.261 & $.019 *$ \\
\hline FUND & $\begin{array}{r}-7.70 \mathrm{E}- \\
05\end{array}$ & 0.563 & 0 & 0.513 & $\begin{array}{r}1.30 \mathrm{E}- \\
05\end{array}$ & 0.695 & $\begin{array}{r}-1.50 \mathrm{E} \\
-05\end{array}$ & 0.48 \\
\hline LAUNCH & -17.33 & 0.194 & -38.2 & 0.144 & 0.242 & 0.79 & -4.55 & $.013 *$ \\
\hline MGR & 47.99 & 0.116 & 176.7 & 0.337 & 5.85 & 0.164 & -1.85 & 0.839 \\
\hline
\end{tabular}

Dependent variable: RET.

Table I shows the test results of four models. Model 1 is a model using all types of Islamic mutual funds. Model 2 only uses stock mutual funds. Model 3 only uses fixed income mutual funds. Model 4 only uses mixed mutual funds.

\subsection{The Persistence of Sharia Mutual Fund Performance}

Performance persistence occurs when good performance in a certain period will continue in the next period. In this study, we used two proxies to test the persistence, which are based on the previous period return (RTM1) and the relative performance in the form of the best performance, Top 5, in the previous period (TOP5). The results of our study, as shown in Table I, show that these two variables are not significant in almost all models, except the TOP5 variable in the fixed income mutual funds model. Thus, it can be concluded that: (1) in general, the performance of Islamic mutual funds in Indonesia is not persistent; (2) the Islamic stock mutual funds is not persistent; (3) the Islamic mixed mutual funds is not persistent; and (4) the Islamic fixed income mutual funds is persistent when using relative performance, but not persistent if using absolute performance.

The results of this study are generally in line with the results of previous studies such as the research of Dwianggoro et al. (2012), who found that there was no persistence of mutual fund performance for five years and above. This research has a duration of nine years and generally does not find performance persistence, thus it is consistent with the findings of Dwianggoro et al. (2012). This study also reinforces Arifin's research (2018), which found persistence for the period 20102011 and did not find persistence for the 2012-2016 period. This study used a longer period, 2010-2018, and found that in general there was no performance persistence except for fixed income mutual funds.

The persistence of performance in fixed income mutual funds is quite interesting. This type of mutual fund is indeed relatively easier to predict because it contains bond securities that have a relatively low level of uncertainty. The bond risk will arise when interest rates change. However, this risk will only arise when the bond is traded. If the bond is held to maturity, then the interest rate risk only appears if, when replacing old bonds with new bonds, there is a decrease in market interest rates. This will result in a decrease in bond yields, which will reduce the performance. The persistence of fixed income mutual funds performance in Indonesia could be because it is supported by the benchmark interest rate in Indonesia, which was relatively stable in the period 2010-2018 at around 6$8 \%$.

\subsection{Capital Market Performance and Mutual Fund Performance}

In the study of IPOs, there was a behavior that companies tended to choose to do an IPO when the prospects of the capital market were perceived as good. 
This condition became known as "hot IPO." At that time, investors also benefited because they would get a larger initial return, as found by Agathee, Brooks, and Sannassee (2012). This study adopted the concept of "hot IPO" in the study of mutual funds. The more mutual funds that are issued in a year, the better is the investor's perception of the prospect of mutual funds that year.

This study found that, during "hot issue," mixed mutual funds provided a greater return than during "cold issue," as shown in the HOT p-value variable in Table I (0.019). However, this finding only exists in mixed mutual funds; in stock mutual funds and fixed income mutual funds, there is no effect of the condition of the capital market on sharia mutual fund performance. he number of new mixed mutual funds during the study period is indeed relatively small, i.e., only 16 mutual funds, while there are 52 new equity mutual funds and 35 fixed income funds. Complete data on new mutual funds can be seen in Table II.

Table 2. Number of new sharia mutual funds during 2011-2018.

\begin{tabular}{|l|l|l|l|l|l|}
\hline Year & $\begin{array}{l}\text { Stock Mutual } \\
\text { Funds }\end{array}$ & $\begin{array}{l}\text { Fixed Income } \\
\text { Mutual Funds }\end{array}$ & $\begin{array}{l}\text { Mixed Mutual } \\
\text { Funds }\end{array}$ & Others & Total \\
\hline 2011 & 0 & 0 & 0 & 2 & 1 \\
\hline 2012 & 4 & 0 & 2 & 0 & 7 \\
\hline 2013 & 4 & 0 & 4 & 0 & 8 \\
\hline 2014 & 7 & 0 & 2 & 13 & 19 \\
\hline 2015 & 2 & 4 & 0 & 16 & 43 \\
\hline 2016 & 13 & 13 & 1 & 25 & 46 \\
\hline 2017 & 8 & 9 & 4 & 16 & 42 \\
\hline 2018 & 14 & 9 & 3 & 73 & 176 \\
\hline Total & 52 & 35 & 16 & & 9 \\
\hline
\end{tabular}

Source: OJK Sharia Mutual Fund Statistics April 2019, data processed.

The annual new mixed mutual funds issued at most were only four in 2013 and 2017. If we look at the data, mixed mutual funds actually have never experienced a "hot issue." It is different from stock mutual funds and fixed income mutual funds that have experienced hot issues, namely in 2016, each of which has 13 new mutual funds; and in 2018 there were 14 new equity mutual funds and 9 new fixed income mutual funds. Looking at these data, the effect of hot issues on the performance of mutual funds in the case of mixed mutual funds is less strong because the hot issue in mixed Islamic mutual funds is less visible.

\subsection{Characteristics of Mutual Funds and Mutual Fund Performance}

There are three proxies used in this study related to the characteristics of mutual funds: the amount of funds under management (FUND), the length of the mutual fund has been issued or effective (LAUNCH), and the fund manager is domestic or foreign (MGR). The test results in Table I show that the amount of funds under management and fund manager type do not affect the performance of mutual funds for the four test models.
The duration of effective mutual funds has a significant negative effect on mixed mutual funds but does not affect other types of mutual funds.

The amount of funds under management reflects the level of investor confidence in the investment manager. Investors will certainly choose mutual funds that provide the greatest benefits based on their last performance. If the performance of the mutual funds can be maintained, the greater is the amount of funds under management, the greater is the return of the mutual funds. However, the results of this study do not show this. The amount of funds under management did not affect the performance of mutual funds.

Regarding investment managers, there is an assumption that foreign investment managers have better capabilities because foreign management is considered more experienced and has a wider network, thus their access to information is considered better. For this reason, foreign investment managers are perceived to have the ability to choose investments that are better than domestic investment managers. However, this study did not find foreign manager dominance over domestic managers in choosing securities. 
The third characteristic of mutual funds analyzed in this study is how long mutual funds have been issues. If guided by the learning curve concept, the longer since a mutual fund launched, the better is the ability of the mutual fund managers. Thus, it is expected that mutual funds launched longer ago would have better performance. However, this study did not find any effect on the length since launch on the performance of mutual funds types of stocks and fixed income. Even for mixed mutual funds, the effect of the length of launching on performance is negative. The negative effect of the length of launching on the performance of Islamic mutual funds is probably related to the relationship of stock returns in the capital market, which tends to be negative. This negative return relationship pattern was used by De Bondt and Thaler (1985) as evidence of the overreaction behavior of investors in the capital market. When there is good news, investors respond excessively so that stock prices increase higher than they should. This will result in a decrease in stock prices in the next period to adjust for the excessive price increase. Thus, the price increase will be followed by a decrease in prices so that the pattern of return on the capital market becomes negative.

\section{CONCLUSION AND IMPLICATION}

In summary, this study found that: (1) there is no performance persistence for equity mutual funds and mixed mutual funds; (2) there is persistence of performance for fixed income mutual funds; (3) "hot and cold issue" conditions do not affect sharia mutual fund performance, except in mixed mutual funds; (4) the amount of funds in managed funds does not affect the performance; (5) the performance of managers of foreign Islamic mutual funds is not different from those of domestic sharia mutual fund managers; and (6) the duration of issuance has a negative effect on the performance of mixed mutual funds but not on other mutual funds.

From the findings above, the easiest strategy is to invest in sharia fixed income mutual funds, and to choose the funds that occupy the Top 5 in the previous period. To invest in mixed mutual funds, choose newly issued mixed mutual funds, especially when that year there are several new mixed mutual fund products. For stock mutual funds, there seems to be no specific strategy that can be done. Perhaps when referring to Carhart's (1997) findings, the strategy for choosing stock mutual funds is to choose mutual funds with the cheapest transaction costs and when the stock market is expected to be in good prospect.

\section{RESEARCH LIMITATIONS}

This study uses only six factors to predict sharia mutual fund performance. Among the six factors, only three factors effectively influence the performance. Future research may look for other factors to increase alternative strategies to invest in sharia mutual fund, especially for stock sharia mutual fund, for which we did not find a specific strategy.

\section{ACKNOWLEDGMENTS}

We would like to thank the Directorate of Research and Community Service in the Indonesian Ministry of Research, Technology and Higher Education, who has given grants for this research. We would also like to thank our colleagues at the Management Department of the Islamic University of Indonesia, who have provided many criticisms of the draft research proposal and also the results of the research.

\section{REFERENCES}

[1] Arifin, Z. 'Testing for persistence in sharia mutual fund performance in Indonesia'. Review of Integrative Business and Economics Research, 7(1), 2018, pp. 104-115.

[2] Arifin, Z. and Mulyati, S. 'Relative short-term persistence and absolute short- term persistence of Islamic mutual funds in Indonesia'. Advances in Economics, Business and Management Research (AEBMR), 35, 2017, pp. 94-100.

[3] C. Baier, J-P. Katoen, Principles of Model Checking, MIT Press, 2008.

[4] Arouri, M. and Teulon, F. 'Persistence of performance using the four-factor pricing model: evidence from Dow Jones Islamic index'. The Journal of Applied Business Research, 30(3), 2014, pp. 917-926.

[5] Bodie, Z., Kane, A. and Marcus, A. J. Investment (10th ed). McGraw-Hill Education, USA, 2014.

[6] Carhart, M. M. and Mark. 'On persistence in mutual fund performance'. The Journal of Finance, 52(1), 1997, pp. 57-82.

[7] Chen, D. H., Chuang, C. L., Lin, J. R. and Lan, C. L. 'Market timing and stock selection ability of mutual fund managers in Taiwan: applying the traditional and conditional approaches'. International Research Journal of Applied Finance, 4(1), 2013, pp. 76-98.

[8] Cuthbertson, K. and Nitzsche, D. 'Performance, stock selection and market timing of the German equity mutual fund industry'. Journal of Empirical Finance, 21, 2013, pp. 86-101.

[9] De Bondt, W. F. M. and Thaler, R. 'Does the stock market overreact?' The Journal of Finance, 40(3), 1985, pp. 793-805. 
[10] Dwianggoro, A., Anantadjaya, S. P. and Sibarani, M. 'Equity mutual funds in Indonesia: persistence analysis period April 2006 - March 2011'. Finance \& Accounting Journal, 1(2), 2012, pp. 69-83.

[11] Fama, E. F. and French, K. R. 'Common risk factors in the returns on bonds and stocks'. Journal of Financial Economics, 33(1), 1993, pp. 3-56.

[12] Grinblatt, M. and Titman, S. 'The persistence of mutual fund performance'. The Journal of Finance, 47(5), 1992, pp. 1977-1984.

[13] Gruber, M. J. and Martin. 'Another puzzle: the growth in actively managed mutual funds'. The Journal of Finance, 51(3), 1996, pp. 783-810.

[14] Jegadeesh, N. and Titman, S. 'Returns to buying winners and selling losers: implications for stock market efficiency'. Journal of Finance, 48(1), 1993, pp. 65-91.

[16] Jones, S., van der Laan, S., Frost, G. and Loftus, J. 'The investment performance of socially responsible investment funds in Australia'. Journal of Business Ethics, 80(2), 2008, pp. 181-203.

[17] Mansor, F. and Bhatti, M. I. 'The Islamic mutual fund performance: new evidence on market timing and stock selectivity' Proceeding 2011 international conference on economics and finance research (ICEFR). Lengkawi Malaysia.

[18] 'Otoritas jasa keuangan. Statistik Reksadana Syariah April 2019 (Sharia mutual fund statistics April 2019).

[19] Subadar Agathee, U. S., Brooks, C. and Sannassee, R. V. 'Hot and cold IPO markets: the case of the Stock Exchange of Mauritius'. Journal of Multinational Financial Management, 22(4), 2012, pp. 168-192.

[20] Zheng, L. 'Is money smart? A study of mutual fund investor's fund selection ability'. The Journal of Finance, LIV(3), 1999, pp. 901-933. 